\title{
An evaluation of exogenous enzymes with amylolytic activity for dairy cows
}

\author{
C. M. Klingerman, W. Hu, E. E. McDonell, M. C. DerBedrosian, and L. Kung Jr. ${ }^{1}$ \\ Department of Animal and Food Sciences, University of Delaware, Newark 19716-2150
}

\section{ABSTRACT}

An experimental (7B) and a commercial (AMA) formulation of enzymes, both primarily with $\alpha$-amylase activity, were evaluated for activity at various $\mathrm{pH}$ values, stability in ruminal fluid, the potential to improve in vitro ruminal fermentations, and the potential to improve production performance of lactating cows. When incubated $\left(40^{\circ} \mathrm{C}\right)$ in buffer with a $\mathrm{pH}$ between 5.4 and 6.0,7B had about 10 to 25 times greater amylase activity than AMA, and enzyme activity in this range increased by $100 \%$ for $7 \mathrm{~B}$, whereas activity decreased by about $26 \%$ for AMA. Both formulations maintained enzyme activity when they were incubated in in vitro ruminal fermentations for $24 \mathrm{~h}$. After $6 \mathrm{~h}$ of ruminal in vitro fermentation, additions of $7 \mathrm{~B}$ resulted in linear increases in apparent total volatile fatty acid production for flint and dent corn but had no effect on floury corn. In a lactation trial, 28 Holstein cows $(68 \pm 31 \mathrm{~d}$ in milk, $46.9 \pm 9.1 \mathrm{~kg}$ of milk/d) were fed a total mixed ration (TMR) supplemented with nothing (CON), a low dose of $7 \mathrm{~B}[7 \mathrm{BL}, 0.88 \mathrm{~mL} / \mathrm{kg}$ of TMR dry matter $(\mathrm{DM})]$, a high dose of $7 \mathrm{~B}(7 \mathrm{BH}, 4.4 \mathrm{~mL} / \mathrm{kg}$ of $\mathrm{TMR}$ DM), or AMA (0.4 g/ $\mathrm{kg}$ of TMR DM). The experiment was conducted as a $4 \times 4$ Latin square design with 21-d periods. Cows fed 7BL, 7BH, and AMA ate similar amounts of DM, and cows fed the latter 2 diets consumed more DM than did cows fed CON. Cows fed 7BL produced more milk than cows fed $\mathrm{CON}$ and $7 \mathrm{BH}$, but produced similar amounts to cows fed AMA. The production of $3.5 \%$ fat-corrected milk was greater from cows fed 7BL and AMA compared with cows fed CON. The percentages of milk fat and milk protein were unaffected by treatment. Total-tract digestion of DM and organic matter were greater for cows fed 7BL compared with those fed CON. The addition of exogenous amylase enzymes to the diets of lactating dairy cows has the potential to improve animal productivity.

Key words: amylase, enzyme, lactation

\section{INTRODUCTION}

Several studies have shown that some exogenous enzymes are resistant to degradation in the rumen

Received May 7, 2008.

Accepted October 29, 2008

${ }^{1}$ Corresponding author: lksilage@udel.edu
(Hristov et al., 1998) and thus have the potential to increase the digestibility of feeds and subsequently improve animal performance. Adding fibrolytic enzymes to ruminant diets has been the topic of many studies (Beauchemin et al., 2003) because digestion of fiber is usually never maximized in the rumen. Although digestion of starch in the rumen is not generally thought to be limiting, there is some in vitro and in vivo evidence suggesting that amylase enzymes also have the potential to improve animal performance. In an in vitro evaluation, Rojo-Rubio et al. (2001) reported that an amylase from Bacillus licheniformis increased in vitro ruminal starch digestion of sorghum and corn. In situ digestion of starch in steers has also improved with amylase enzymes. Mora-Jaimes et al. (2002) reported improvements in rumen digestion of starch when sorghum was treated with $\alpha$-amylase from $B$. licheniformis ( $82.85 \%$ digestion) or glucoamylase from Aspergillus niger $(87.23 \%)$ compared with untreated feed $(75.13 \%$ digestion).

A commercial additive with amylase activity (Amaize, Alltech Inc., Nicholasville, KY) has recently been evaluated in several studies. Tricarico et al. (2005) reported a quadratic response in milk production when cows were fed this product. In a large field study, Harrison and Tricarico (2007) found that feeding this additive increased milk production by $1 \mathrm{~kg} / \mathrm{d}$. Tricarico et al. (2007a) also reported that the same additive increased ADG of beef steers when cottonseed (but not alfalfa) was the forage source.

The objective of the present study was to evaluate the potential use of an experimental amylase enzyme and compare its ability to a commercial enzyme product for improving the performance of lactating dairy cows. Our hypothesis was that the amylase enzymes used in this study would be stable in a rumen environment and thus, when added to feeds would have the ability to improve starch digestibility and subsequent animal production.

\section{MATERIALS AND METHODS}

\section{Evaluation of Enzyme Activity}

Three enzyme products with primarily $\alpha$-amylase (EC 3.2.1.1) activity were evaluated in vitro. The first product was a dry commercial feed additive for dairy 
cattle (AMA, Amaize, batch number 251528, Alltech Inc.). The product contained Saccharomyces cerevisiae fermentation solubles and Aspergillus oryzae extract. The second product was an experimental enzyme formulation in liquid form (7B, lot numbers AUP 50025, AUP 50038, and AUP 50052) supplied by Dutch States Mines (Heerlen, the Netherlands). The third product, a reagent-grade $\alpha$-amylase in liquid form from A. oryzae, served as a positive control (SAM; Sigma A8220, Sigma-Aldrich, St. Louis, MO). All 3 enzyme products were assayed for $\alpha$-amylase activity using an enzyme kit (K-CERA) from Megazyme International (Bray Business Park, Bray, Co. Wicklow, Ireland) based on a method of McCleary et al. (2002; AOAC method 2002.01). $\alpha$-Amylase activity was determined by dissolving the enzymes in a buffer mix containing malic acid, sodium hydroxide, sodium chloride, calcium chloride $\cdot 2 \mathrm{H}_{2} \mathrm{O}$, and sodium azide. The solutions were clarified by centrifuging an aliquot of the preparations at $1,000 \times g$ for $10 \mathrm{~min}$. Appropriate dilutions were prepared for each product for absorbance readings to be within the range of the standards. A color reagent containing blocked $p$-nitrophenyl maltoheptaoside and thermostable $\alpha$-glucosidase was preincubated separately from the diluted enzyme at $40^{\circ} \mathrm{C}$ for $5 \mathrm{~min}$. A sample of the diluted enzyme was then added directly to the bottom of the tube containing the reagent described and incubated for exactly $10 \mathrm{~min}$ at $40^{\circ} \mathrm{C}$. At the end of the incubation period, $3.0 \mathrm{~mL}$ of a stopping reagent $(20 \%$ trisodium phosphate) was added to terminate the reaction. Release of $p$-nitrophenol as the reaction product was measured as the absorbance of the solution at 400 $\mathrm{nm}$ on a spectrophotometer (Jenway 6300, Burlington, NJ) against deionized water. A sample of wheat flour with known $\alpha$-amylase activity was included as a control with each assay. A blank sample containing only the stopping reagent, color reagent, and enzyme preparation was used to account for residual activity of the buffer. The enzyme products were tested in duplicate over a range of $\mathrm{pH}$ (5.1 to 6.3 ) by adjusting the $\mathrm{pH}$ of the buffer mix using $6 \mathrm{~N} \mathrm{HCl}$. Activity was expressed as Ceralpha units $(\mathbf{C U})$ where one $\mathrm{CU}$ was the amount of enzyme in the presence of excess amylase required to release one micromole of $p$-nitrophenol from blocked $p$-nitrophenyl maltoheptaoside in one minute under the specific assay conditions.

The 7B and AMA enzyme preparations were further tested for enzyme activities by Novozymes A/S (Bagsvaerd, Denmark). Activities of protease (substrate = denatured hemoglobin, $40^{\circ} \mathrm{C}, \mathrm{pH} 4.7$ ) and cellulase (substrate $=$ carboxymethylcellulose, $40^{\circ} \mathrm{C}, \mathrm{pH} 7.5$ ) were all below the detection limit of their assays. Activities for cellulase (substrate $=$ dyed insoluble Avicel, $50^{\circ} \mathrm{C}$, $\mathrm{pH} 6.0$ ), $\beta$-glucanase (substrate $=\beta$-glucan, $50^{\circ} \mathrm{C}, \mathrm{pH}$
5.0), and xylanase (substrate $=$ wheat arabinoxylan, $50^{\circ} \mathrm{C}, \mathrm{pH} 6.0$ ) were only slightly higher than the detection limit of their assays (data not shown). The AMA preparation contained $27.8 \% \mathrm{CP}$ and the $7 \mathrm{~B}$ preparation contained $2.2 \% \mathrm{CP}$ (wt/wt).

\section{Stability of Amylase Enzymes in In Vitro Ruminal Fermentations}

The enzymes were also tested for stability of $\alpha$-amylase activity over time in ruminal fermentations using the in vitro method of Goering and Van Soest (1970) with some modifications. The modifications included the use of sealed polycarbonate tubes that were gassed with $\mathrm{CO}_{2}$ and incubated at $40^{\circ} \mathrm{C}$ in a water bath and shaken manually approximately once every hour for $6 \mathrm{~h}$ and then every $6 \mathrm{~h}$ thereafter. Enzymes were tested by adding $1.0 \mathrm{~mL}$ of $7 \mathrm{~B}$ or $\mathrm{SAM}$ or $1.0 \mathrm{~g}$ of AMA to $50 \mathrm{~mL}$ of ruminal fluid and buffer (1:4). After 0, 3, 6, and $24 \mathrm{~h}, 2.0 \mathrm{~mL}$ of fluid was removed from each tube. Fluid was immediately centrifuged $(10,000 \times g)$ for 5 min, and the supernatant was filtered through sterile $0.25-\mu \mathrm{m}$ filters (Millex, PVDF Durapure syringe filters, Millipore Corp., Bedford, MA). The residual $\alpha$-amylase activity in the sterile fluid was measured as described previously.

\section{Effect of Amylase Enzymes on In Vitro Ruminal Fermentation of Corn}

A preliminary study was conducted to determine if 7B could improve the in vitro ruminal fermentation of various types of corn. Two hundred fifty milligrams of floury (vitreousness $=0$ ), dent (vitreousness $=62$ ), or flint (vitreousness $=100$ ) corn grain (P. Hoffman, University of Wisconsin, Marshfield, WI) was ground through a 2.0-mm screen using a Cyclone Sample Mill (Udy Corp., Fort Collins, CO) and weighed into 50-mL polycarbonate tubes. These samples were from a database used by Blasel et al. (2006). Ruminal fluid and some particulate matter was collected from a rumenfistulated steer fed a 50\% forage:50\% concentrate diet (DM basis) 3 to $4 \mathrm{~h}$ after the a.m. feeding. A plastic bottle was inserted through the rumen fistula (filled to capacity) and sealed immediately. Within 10 min of collection, the fluid and particulate matter were strained through 8 layers of cheesecloth into a prewarmed beaker purged with anaerobic-grade $\mathrm{CO}_{2}$. Twenty milliliters of buffer (Goering and Van Soest, 1970) containing 7B enzyme to supply $0,0.88,2.6$, or $4.4 \mathrm{~mL}$ of enzyme/ $\mathrm{kg}$ of corn DM and $10 \mathrm{~mL}$ of strained ruminal fluid were added to tubes containing the various types of corn. Five replicate tubes were prepared for each type of corn and the experiment was replicated on 2 separate 
days. Tubes were incubated under anaerobic conditions in an orbital shaker at $120 \mathrm{rpm}$ and $40^{\circ} \mathrm{C}$. After $6 \mathrm{~h}$, tubes were stirred vigorously, and $3.0 \mathrm{~mL}$ of fluid was removed and acidified using $75 \mu \mathrm{L}$ of $6 N \mathrm{HCl}$. Samples were centrifuged at $10,000 \times g$ for $5 \mathrm{~min}$. The supernatant $(1.0 \mathrm{~mL})$ was added to $200 \mu \mathrm{L}$ of metaphosphoric acid in glass vials (C4011-1W, National Scientific, Rockwood, TN), capped with crimp seals, and inverted to ensure adequate mixing. Volatile fatty acid analysis was performed on the samples by GC (Model 5890, Series II, Agilent, Wilmington, DE) using a $10 \mathrm{~m} \times$ $0.53 \mathrm{~mm}$ (i.d.) Stabilwax-DA column with $0.25-\mathrm{mm}$ thickness (Restek Co., Bellefonte, PA). Helium was used as a carrier with a flow rate of $10 \mathrm{~mL} / \mathrm{min}$. One microliter of sample was injected at a split ratio of 8:1. Injection port temperature was $250^{\circ} \mathrm{C}$ and the detector temperature was $300^{\circ} \mathrm{C}$. The oven temperature was programmed as follows: $90^{\circ} \mathrm{C}$ for $0.5 \mathrm{~min}$, with a $2^{\circ} \mathrm{C}$ increase $/ \mathrm{min}$ to $100^{\circ} \mathrm{C}, 15^{\circ} \mathrm{C}$ increase/min to $200^{\circ} \mathrm{C}$, and a final holding time of $2 \mathrm{~min}$. Apparent production of total VFA was calculated with corrections for rumen fluid and buffer blanks.

\section{Lactation Trial}

The 7B and AMA enzyme formulations were tested further with lactating cows. This study was approved by the Animal Care Committee, Department of Animal and Food Sciences, University of Delaware and followed approved guidelines (Anonymous, 1998; FASS, 1999). Twenty-eight Holstein cows were housed in a barn with sand-bedded free-stalls and fed individually via a system with Calan gates (American Calan, Northwood, $\mathrm{NH}$ ).

Cows were fed a diet to meet requirements for cows producing $47.7 \mathrm{~kg}$ of milk/d with a fat test of $3.6 \%$, consuming $27.6 \mathrm{~kg} / \mathrm{d}$ of DM and averaging $636 \mathrm{~kg}$ of BW. Feed ingredients were mixed to form a TMR containing 50\% concentrate (Table 1), 37\% corn silage, $7 \%$ alfalfa haylage, and $6 \%$ alfalfa hay (analysis of the forages are shown in Table 2). Cows were fed their TMR once daily, ad libitum at approximately $0700 \mathrm{~h}$, and individual feed refusal was measured daily. Cows had access to fresh water at all times. After a 2-wk adjustment period, cows were blocked based on pretreatment milk production (average of $46.9 \pm 9.1 \mathrm{~kg} / \mathrm{d}$ ), DMI (average of $25.6 \pm 3.1 \mathrm{~kg} / \mathrm{d}$ ), BW (average of $723 \pm$ $81 \mathrm{~kg}$ ), BCS (average of $2.83 \pm 0.31$ ), lactation number (average of $3.11 \pm 1.89$ ), and DIM (average of $68 \pm$ 40 DIM) and randomly assigned to 1 of 4 treatments. The study design was a replicated $4 \times 4$ Latin square design with 21-d periods, with the last $7 \mathrm{~d}$ used for data collection. The treatments were 1) a diet without addition of an enzyme formulation (CON); 2) a diet containing $0.88 \mathrm{~mL}$ of the $7 \mathrm{~B}$ enzyme formulation per $\mathrm{kg}$ of TMR DM (7BL); 3) a diet containing $4.4 \mathrm{~mL}$ of the 7B enzyme formulation per $\mathrm{kg}$ of TMR DM $(\mathbf{7 B H})$; or 4) $0.4 \mathrm{~g}$ of AMA per kg of TMR DM. The concentrations of enzyme 7B were based on preliminary studies conducted by Dutch States Mines (unpublished data), and the level of AMA was chosen as it supplied similar amounts of amylase activity as used in previous studies (Tricarico et al., 2005, 2007a). The amylase enzymes used for treatments 7BL and 7BH were in a liquid form and they were diluted in water just before spraying onto only the concentrate. (The amount of water applied was approximately $20 \mathrm{~L}$ per 1,000 kg of TMR DM.) A similar amount of water was added to the concentrates of CON and AMA. The diluted enzymes (7BL, 7BH) or water (CON, AMA) were applied to an amount of concentrate that was enough for the entire treatment group using a hand-held sprayer. After water was added to the concentrate of AMA, the dry formulation of enzyme was mixed into the concentrate. After mixing, the treated concentrates was combined with the forage components to form a TMR. The enzymes were applied to the concentrate first because this component of the diet is usually highest in starch. In addition, Canadian researchers have suggested that application of liquidbased enzymes to diets for lactating dairy cows is more effective when they are applied to the dry portion of the diet (Beauchemin et al., 2003) and not to the entire TMR that contains silage (Yang et al., 2000; Bowman et al., 2002). This may be because wet silages might contain inhibitory compounds produced during fermentation that could reduce the effectiveness of exogenous enzymes (Beauchemin et al., 2003).

Silage and TMR were sampled 3 times a week, and concentrate and hay were sampled once a week. Samples were frozen and each feed type was pooled together weekly for analysis. Dry matter of the silages was determined in a forced-draft oven set at $60^{\circ} \mathrm{C}$ for $48 \mathrm{~h}$. Dry matter of the hay and concentrates was determined in a forced-draft oven set at $100^{\circ} \mathrm{C}$ for $12 \mathrm{~h}$. The DM content of feeds was used for weekly adjustment of the TMR. Feeds were analyzed by wet chemistry methods by Cumberland Valley Analytical (Maugansville, MD). Crude protein was calculated as $\mathrm{N} \times 6.25$ after analyses of N (AOAC, 2000) using a Leco FP-528 Nitrogen Combustion Analyzer (Leco, St. Joseph, MI). Soluble protein (Krishnamoorthy et al., 1982) and starch (Holm et al., 1986) were also determined on samples of the TMR. The ADF (AOAC, 2000) and NDF (Goering and Van Soest, 1970) contents of feeds were determined with the modification that Whatman 934-AH glass micro-fiber filters (Whatman, Florham Park, NJ) with 1.5- $\mu \mathrm{m}$ particle retention were used in place of fritted glass crucibles. 
Table 1. Composition (\% of DM) of concentrate mixed into the TMR in the lactation trial

\begin{tabular}{lc}
\hline Ingredient & $\%$ \\
\hline Corn meal & 36.40 \\
Wheat middlings & 17.66 \\
Distillers dried solubles & 11.60 \\
Soybean meal & 10.66 \\
Aminoplus ${ }^{1}$ & 5.80 \\
Corn gluten meal & 5.00 \\
Fat & 3.26 \\
Soy hulls & 1.68 \\
Sodium bicarbonate & 1.63 \\
Megalac & 1.57 \\
Limestone & 1.46 \\
Dynamate & 1.07 \\
Salt & 0.91 \\
Urea $_{\text {XP yeast }}{ }^{3}$ & 0.42 \\
Magnesium oxide & 0.37 \\
Pennfield Quadra & 0.16 \\
Selenium, 0.06\% & 0.13 \\
Organic selenium premix, 120 ppm & 0.07 \\
Niacin, 99\% & 0.07 \\
Mix of vitamins A, D, and $\mathrm{E}^{6}$ & 0.03 \\
Ruminant trace minerals & \\
\hline
\end{tabular}

${ }^{1} \mathrm{~A}$ source of ruminally protected soybean meal (Ag Processing Inc., Omaha, NE).

${ }^{2}$ Calcium salts of long-chain fatty acids. Minimum fat of $82.5 \%, \mathrm{NE}_{\mathrm{L}}$ of $5.20 \mathrm{Mcal} / \mathrm{kg}$ (Church and Dwight Co. Inc., Princeton, NJ).

${ }^{3}$ Minimum of $22 \%$ S, $18 \%$ K, $11 \%$ Mg (Mar-Gro, Lancaster, PA).

${ }^{4}$ Derived from Saccharomyces cerevisiae (Diamond V Mills, Cedar Rapids, IA).

${ }^{5}$ Minimum of $2 \% \mathrm{Zn}, 3.75 \% \mathrm{Mn}$, and $6.75 \% \mathrm{Zn}$ as metal proteinates (Pennfield Co., Lancaster, PA).

${ }^{6}$ Minimum (per kilogram) of 22,000,000 IU of vitamin A, 5,500,000 IU of vitamin D, and 110,000 IU of vitamin E (Pennfield Corp.).

${ }^{7}$ Minimum $8.6 \% \mathrm{Ca}, 1.35 \% \mathrm{Cu}, 4 \% \mathrm{Fe}, 7.5 \% \mathrm{Mn}, 12 \% \mathrm{Zn}, 1,000 \mathrm{mg} / \mathrm{kg}$ of Co, and $2,500 \mathrm{mg} / \mathrm{kg}$ of I (Eastern Minerals Inc., Bainbridge, GA).

Cows were milked twice daily at approximately 0600 and $1500 \mathrm{~h}$, and milk production was recorded automatically via computer. Milk samples were taken at the morning and afternoon milkings on d 19 and 21 of each period. Samples were analyzed by Dairy One Cooperative Inc. (University Park, PA) for milk fat, protein, lactose, and MUN using a Milkoscan System 4000 (Foss North American, Eden Prairie, MN). A Eurochem CL-10 reference analyzer (Eurochem, Rome, Italy) was used for calibration of samples. Cows were weighed on 2 consecutive days at the beginning and completion of each period.
At the conclusion of period 4 , the 6 highest-producing cows from each group continued on their experimental diets. The study design was a completely randomized design with the same 4 treatments. Average daily intake was determined using data from the last week of period 4 , and cows were fed this same amount daily for 8 additional days. From d 5 through 8, fecal grab samples $(\sim 300 \mathrm{~g})$ were collected via rectal palpation every $8 \mathrm{~h}$ (sampling time was increased by $1 \mathrm{~h}$ each day) until a total of 12 samples were collected for each cow. During fecal collections, TMR (from each group) and orts (for each cow) were taken daily. Fecal samples and orts for individual cows and treatment TMR were pooled and dried for $48 \mathrm{~h}$ in a $60^{\circ} \mathrm{C}$ forced-air oven. Samples were ground through a 1-mm screen using a Cyclone Sample Mill (Udy Corp.) and analyzed for ADF and NDF (Goering and Van Soest, 1970), N (Elementor Vario Max CN Analyzer, Elementor Americas Inc., Mt. Laurel, NJ), starch (Cumberland Valley Analytical Laboratory), and ash content $\left(600^{\circ} \mathrm{C}\right.$ in a muffle furnace for 5 h). Indigestible NDF was used as a marker to calculate apparent digestibility from the total tract (Oba and Allen, 1999). Indigestible NDF was determined after $120 \mathrm{~h}$ of in vitro rumen incubation using the method of Goering and Van Soest (1970) with modifications. The modifications included weighing the samples into filter bags and incubating them in buffer and ruminal fluid for $120 \mathrm{~h}$ using a Daisy ${ }^{\mathrm{II}}$ incubator (Ankom Technology, Macedon, NY). Ruminal fluid was collected from a cow fed the control diet. After $60 \mathrm{~h}$ of incubation, the original ruminal fluid and buffer was discarded and replaced with a fresh mixture and incubation continued for an additional $60 \mathrm{~h}$.

\section{Statistical Analysis}

The in vitro ruminal fermentation study evaluating the effect of $7 \mathrm{~B}$ enzyme dose on 3 corn hybrids was analyzed as a $3 \times 4$ factorial arrangement of treatments using the GLM procedure (SAS Institute, 2004) with significance declared at $P<0.05$. Polynomial regressions were conducted for enzyme dose.

In the lactation study, 1 cow was removed from the data set for health reasons not associated with treatments. The DMI and milk production from d 15 to 21 in each experimental period were reduced to means for

Table 2. Average $( \pm \mathrm{SD}) \mathrm{DM}$ and nutrient composition (DM basis) of forages and concentrate used to make the base TMR in the lactation trial

\begin{tabular}{lccrr}
\hline Item & Alfalfa silage & Alfalfa/grass hay & Corn silage & Concentrate \\
\hline DM, \% & $46.87 \pm 3.90$ & $89.62 \pm 1.17$ & $36.72 \pm 1.71$ & $89.44 \pm 1.58$ \\
CP, \% & $23.17 \pm 1.88$ & $13.90 \pm 0.62$ & $8.97 \pm 0.21$ & $23.20 \pm 0.26$ \\
ADF, \% & $29.13 \pm 4.32$ & $42.40 \pm 0.53$ & $25.40 \pm 0.40$ & $7.50 \pm 0.56$ \\
NDF $\%$ & $34.10 \pm 5.56$ & $52.80 \pm 1.82$ & $39.87 \pm 1.46$ & $18.83 \pm 0.74$ \\
\hline
\end{tabular}




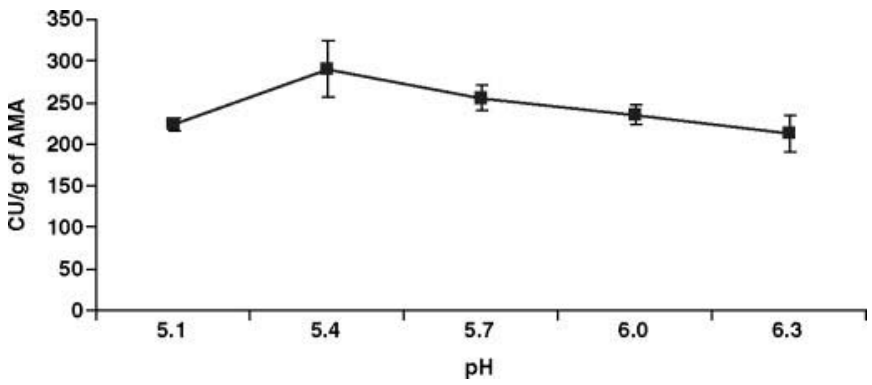

Figure 1. Effect of $\mathrm{pH}$ on the activity of $\alpha$-amylase [measured in Ceralpha units $(\mathrm{CU}) / \mathrm{g}$ ] from a commercial enzyme product (AMA; Alltech Inc., Nicholasville, KY). One CU is the amount of enzyme in the presence of excess thermostable $\alpha$-glucosidase required to release one micromole of $p$-nitrophenol from blocked $p$-nitrophenyl maltoheptaoside in one minute under the specific assay conditions.

each cow. Data were analyzed with the MIXED procedure (SAS Institute, 2004) according to the model for a replicated Latin square design. Cow and period were treated as random variables. Least squares means were compared using the PDIFF option in SAS. The digestion study was conducted as a randomized complete block design and analyzed using the GLM procedure (SAS Institute, 2004). Differences among treatments were compared using Tukey's test (Snedecor and Cochran, 1980). Significance was declared at $P<0.05$ for both studies.

\section{RESULTS}

The enzyme formulations AMA and 7B used in the lactation trials contained primarily $\alpha$-amylase activity and were compared with a reagent-grade product (SAM) also high in $\alpha$-amylase activity. The dry, commercial product AMA had substantially lower $\alpha$-amylase activity when compared with $7 \mathrm{~B}$ and SAM over the range of $\mathrm{pH}$ at which they were tested. The $\alpha$-amylase activity of AMA was greatest at a $\mathrm{pH}$ of 5.4 (Figure 1), with approximately $290 \mathrm{CU} / \mathrm{g}$. Different lots of $7 \mathrm{~B}$ used during the lactation trial had similar $\alpha$-amylase activity with the greatest enzyme activity (approximately 6,400 CU/ $\mathrm{mL}$ ) being expressed at a $\mathrm{pH}$ of 6.0 (Figure 2). Overall, SAM had the highest $\alpha$-amylase activity of all enzymes tested with $32,000 \mathrm{CU} / \mathrm{mL}$ at a $\mathrm{pH}$ of 5.4 (Figure 3). Amylase activity of the 3 enzymes remained relatively constant throughout the $24 \mathrm{~h}$ of incubation in buffer and ruminal fluid (Figure 4).

A preliminary study showed that differences in apparent in vitro ruminal production of total VFA could be detected for flint, dent, and floury corn (data not shown). When different doses of the 7B enzyme were added to the various types of corn, there was a corn $\times$ enzyme interaction (Table 3 ) for VFA production. Specifically, there was a linear effect of enzyme dose on

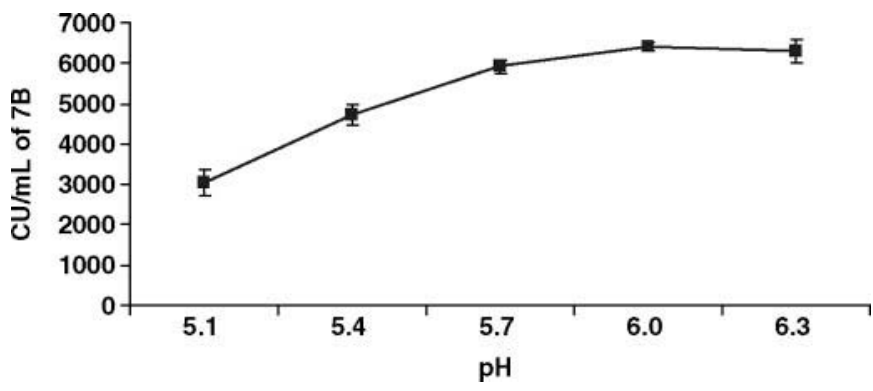

Figure 2. Effect of $\mathrm{pH}$ on the $\alpha$-amylase activity [measured in Ceralpha units $(\mathrm{CU}) / \mathrm{mL}$ ) of an experimental enzyme product $(7 \mathrm{~B}$, Dutch States Mines, Heerlen, the Netherlands). One CU is the amount of enzyme in the presence of excess thermostable $\alpha$-glucosidase required to release one micromole of $p$-nitrophenol from blocked $p$-nitrophenyl maltoheptaoside in one minute under the specific assay conditions.

dent and flint corn but not for floury corn. Addition of 7B enzyme without corn (substrate) to ruminal fluid and buffer did not affect VFA production (data not shown).

The TMR fed to lactating cows in the lactation trial (Table 4) contained similar amounts of starch (average of $25.8 \%$ ), CP (average of $16.7 \%$ ), $\mathrm{ADF}(18.0 \%$ ), and NDF (29.4\%). Dry matter intake, milk production and composition, feed efficiency, and BW are shown in Table 5. Dry matter intake was greater for cows fed $7 \mathrm{BH}$ and AMA compared with CON, but similar to that of cows fed 7BL. Cows fed 7BL produced more milk than cows fed $\mathrm{CON}$ and $7 \mathrm{BH}$, but produced similar amounts to cows fed AMA. Both 7BL and AMA produced more $3.5 \%$ FCM compared with CON, but amounts were similar to 7BH. Percentages of milk fat and milk protein were unaffected by treatment. However, yield of fat $(\mathrm{kg} / \mathrm{d})$ was similar among enzyme treatments but $7 \mathrm{BL}$ and AMA had greater fat yields than CON. Cows fed 7BL and AMA had similar yields of milk protein $(\mathrm{kg} / \mathrm{d})$ and both produced greater yields compared with cows fed CON. Milk urea nitrogen was similar for cows fed

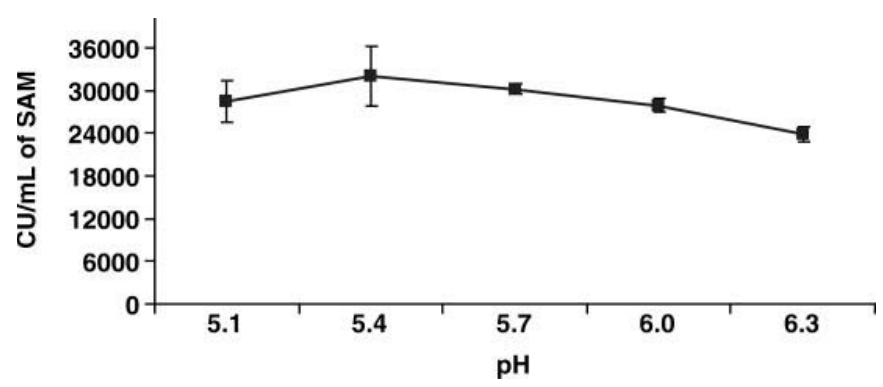

Figure 3. Effect of $\mathrm{pH}$ on the activity of $\alpha$-amylase [measured in Ceralpha units $(\mathrm{CU}) / \mathrm{mL}$ ] from a commercial source of enzyme (SAM; Sigma A8220, Sigma-Aldrich, St. Louis, MO). One CU is the amount of enzyme in the presence of excess thermostable $\alpha$-glucosidase required to release one micromole of $p$-nitrophenol from blocked $p$-nitrophenyl maltoheptaoside in one minute under the specific assay conditions. 


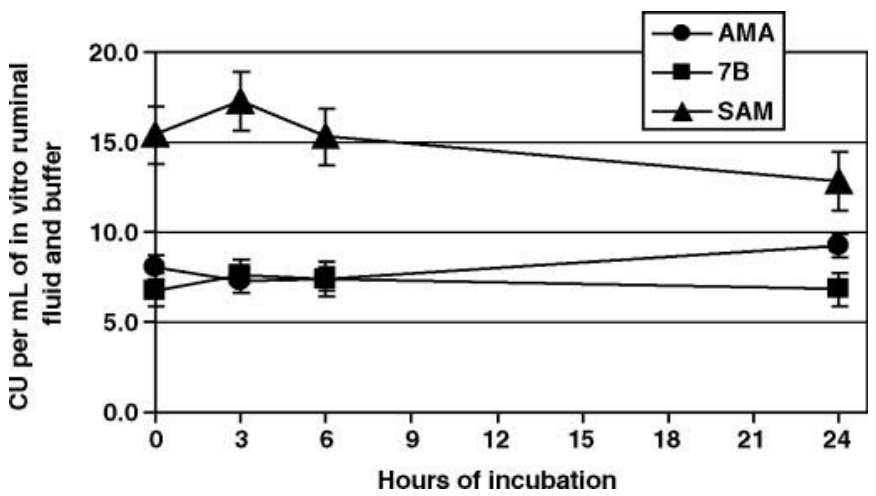

Figure 4. Stability of $\alpha$-amylase activity [measured in Ceralpha units $(\mathrm{CU}) / \mathrm{mL}$ ] of a commercial enzyme product (AMA, Alltech Inc., Nicholasville, KY; $\bullet$ ), an experimental enzyme (7B, Dutch States Mines, Heerlen, the Netherlands; $\mathbf{\square})$, and a reagent-grade enzyme (SAM, Sigma Chemical Co., St. Louis, MO; $\mathbf{\Delta}$ ) in ruminal fluid and buffer after $0,3,6$, and $24 \mathrm{~h}$ of active ruminal incubation. One $\mathrm{CU}$ is the amount of enzyme in the presence of excess thermostable $\alpha$-glucosidase required to release one micromole of $p$-nitrophenol from blocked $p$-nitrophenyl maltoheptaoside in one minute under the specific assay procedures. Note the activity of SAM has been divided by 100 and that of $7 \mathrm{~B}$ by 10 to fit on the graph.

AMA, CON, and 7BL, but greater for cows fed AMA when compared with 7BH. Feed efficiency (FCM/DMI) was greater for cows fed 7BL compared with $7 \mathrm{BH}$, but was similar when compared with CON and AMA. Milk lactose (average of $4.78 \%$ ), BW (average of $752 \mathrm{~kg}$ ), and BW change $/ \mathrm{d}$ (average of $1.31 \mathrm{~kg} / \mathrm{d}$ ) were similar among treatments.

The apparent digestibility of the nutrients in the TMR is shown in Table 6. Digestion of DM and OM was greater for cows fed 7BL compared with those fed $\mathrm{CON}$ and $7 \mathrm{BH}$ but similar to those fed AMA. Cows fed AMA had greater DM and OM digestion than $7 \mathrm{BH}$. The $\mathrm{CP}$ from diets for $\mathrm{CON}, 7 \mathrm{BH}$, and AMA was digested to a similar extent but cows fed 7BL had greater $\mathrm{CP}$ digestion than those fed $7 \mathrm{BH}$. Cows fed $7 \mathrm{BL}$ and AMA had similar digestion of NDF and greater NDF digestion compared with cows fed 7BH. The digestion of NDF was also greater in cows fed $7 \mathrm{BL}$ compared with cows fed CON. The digestion of starch was similar for cows fed CON, AMA, and 7BL, but cows fed the latter treatment had more starch digestion than those fed $7 \mathrm{BH}$.

\section{DISCUSSION}

Various methods have been used to determine the $\alpha$-amylase activity of enzyme formulations used in animal feeds. For example, Hristov et al. (1998) added amylase to ruminal fluid and measured its activity over time by the release of reducing sugars. Walsh et al. (2005) proposed using a radial diffusion method in agar for quantification of enzymes when they were added to animal feeds. In contrast, Tricarico et al. (2005, 2007a, b) and DeFrain et al. (2005) reported the amylase activity of AMA as a dextrinizing unit, where one unit is equal to the amount of enzyme required to degrade starch at a rate of $1 \mathrm{~g} / \mathrm{h}$ at $30^{\circ} \mathrm{C}$ and a $\mathrm{pH}$ of 4.8 (Food Chemicals Codex, 1996). We chose to measure the $\alpha$-amylase activity of the enzyme products used in our study using the Ceralpha assay because it overcomes some of the limitations found in assays based on measuring reducing sugars (Baks et al., 2006) and because it is the standard procedure used by the International Association for Cereal Science and Technology (1998) and has gone through the first action with the Association of Official Analytical Chemists (McCleary et al., 2002). The temperature of the assay is also at $40^{\circ} \mathrm{C}$, which is similar to the rumen environment, and we tested the enzymes over a range of $\mathrm{pH}$ (5.1 to 6.3), which is similar to conditions in the rumen of lactating dairy cows fed rations high in starch. Amylase activity was relatively low (about 10 to 25 times less) for the feed additive AMA compared with the experimental enzyme formulation 7B. However, the enzyme formulation SAM was about 10 times more potent than $7 \mathrm{~B}$ at a $\mathrm{pH}$ of 5.1 and about 4 times more potent than $7 \mathrm{~B}$ at a $\mathrm{pH}$ of 6.3 . The optimum $\alpha$-amylase activities for AMA and SAM were observed at a pH of 5.4 in our study, which is similar to the $\mathrm{pH}$ optimum of $\alpha$-amylases found in Aspergillus fumigatus ( $\mathrm{pH}$ of 5.5; Planchot and Colonna, 1995) and B. subtilis (pH of 5.6; Uguru et al., 1997); however, the activity of these enzymes decreased as $\mathrm{pH}$ increased

Table 3. Effect of adding the experimental enzyme with amylase activity, $7 \mathrm{~B},{ }^{1}$ to different types of corn on production of total VFA after $6 \mathrm{~h}$ of ruminal in vitro fermentation

\begin{tabular}{|c|c|c|c|c|c|}
\hline \multirow[b]{2}{*}{ Corn type } & \multicolumn{4}{|c|}{ Enzyme dose, $\mathrm{mL} / \mathrm{kg}$ of $\mathrm{DM}$} & \multirow[b]{2}{*}{ Significance } \\
\hline & 0 & 0.88 & 2.60 & 4.40 & \\
\hline & \multicolumn{4}{|c|}{ - Total VFA, mM } & \\
\hline Floury & 27.6 & 27.0 & 24.4 & 26.8 & NS \\
\hline Dent & 22.0 & 26.4 & 26.8 & 29.3 & $\begin{array}{c}\text { Linear effect, } \\
\quad P<0.01\end{array}$ \\
\hline Flint & 23.5 & 26.2 & 31.0 & 31.6 & $\begin{array}{c}\text { Linear effect, } \\
\quad P<0.01\end{array}$ \\
\hline
\end{tabular}

${ }^{1}$ Dutch States Mines (Heerlen, the Netherlands). 
Table 4. Average $( \pm \mathrm{SD}) \mathrm{DM}$ and nutrient composition (DM basis) of a TMR not treated $(\mathrm{CON})$ or treated with amylolytic enzymes (7BL, 7BH, AMA) in the lactation trial

\section{Treatment $^{1}$}

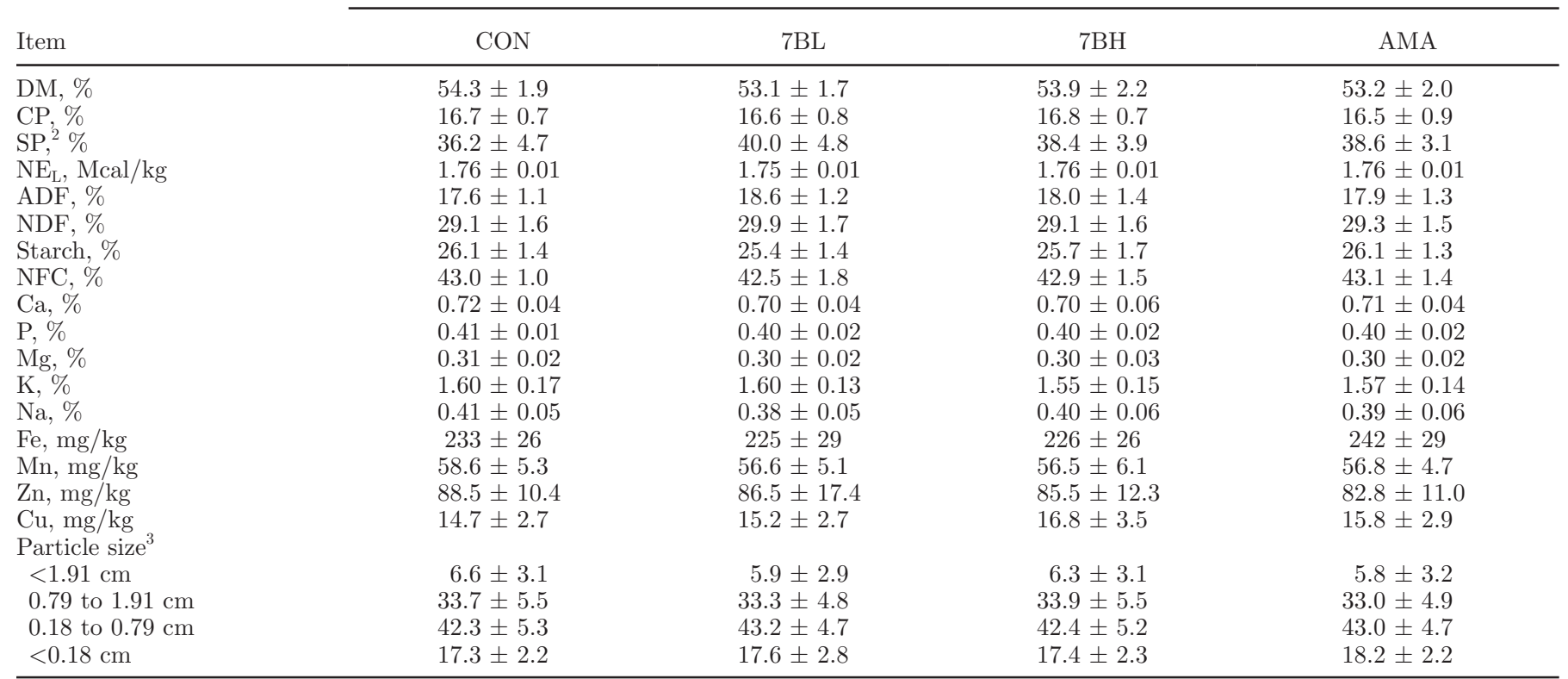

${ }^{1} \mathrm{CON}=$ untreated $($ control $) \mathrm{TMR} ; 7 \mathrm{BL}$ and $7 \mathrm{BH}=\mathrm{TMR}$ treated with a low $(0.88 \mathrm{~mL} / \mathrm{kg}$ of TMR DM) or high $(4.4 \mathrm{~mL} / \mathrm{kg}$ of TMR DM) dose of the experimental amylase enzyme, 7B (Dutch States Mines, Heerlen, the Netherlands); AMA = TMR treated with a commercially available enzyme product (Amaize, Alltech Inc., Nicholasville, KY) with amylase activity, applied at $0.4 \mathrm{~g} / \mathrm{kg}$ of TMR DM.

${ }^{2}$ Soluble protein.

${ }^{3}$ Particle size determined using a Penn State TMR Particle Separator.

above 5.4. In one of the major starch-digesting bacteria in the rumen, Streptococcus bovis JB1, Freer (1993) reported extracellular $\alpha$-amylase activity to be optimal between $\mathrm{pH} 5$ and 6 . In contrast to the activity curves found for AMA and SAM, the activity for $7 \mathrm{~B}$ did not peak until a $\mathrm{pH}$ of 6 and remained high even at a $\mathrm{pH}$ of 6.3. This may be beneficial because the rumen $\mathrm{pH}$ of lactating cows is often between 5.5 and 6.3 (Bach et al., 2007). Similar $\mathrm{pH}$ optimums have been reported for $\alpha$-amylase activity of $A$. oryzae ( $\mathrm{pH} 6$; Singh and Soni, 2001) and B. subtilis AX20 (pH 6; Najafi et al., 2005). All enzyme formulations evaluated in our studies also had $\alpha$-amylase activity that was relatively stable in an in vitro ruminal fermentation over $24 \mathrm{~h}$ suggesting that these enzymes were not subject to extensive degradation by rumen microbes. Hristov et al. (1998) reported similar results when they tested formulations of enzymes with amylolytic activity for stability in ruminal fluid by calculating the release of reducing sugars.

Production of VFA, gases, and microbial cells are the direct end-products of ruminal fermentations. In our laboratory study, we calculated the apparent production of total VFA to evaluate amylase enzymes. We found that addition of various doses of $7 \mathrm{~B}$ amylase enzyme resulted in a linear increase in apparent VFA production after $6 \mathrm{~h}$ of in vitro ruminal fermentation for flint and dent corn samples, but not for floury corn, suggesting that the type of starch may affect the efficacy of the $7 \mathrm{~B}$ preparation. However, in general these results support previous studies that have shown that amylase enzymes can improved the fermentation of grains for ruminants. For example, Velasco (2004) added amylase enzymes at 2,4 , and $6 \mathrm{~g} / \mathrm{kg}$ of sorghum and reported improved in vitro DM digestion after 6 and $12 \mathrm{~h}$ of fermentation but this effect was not observed after 24 and $48 \mathrm{~h}$. Mora-Jaimes et al. (2002) reported that 0.6 to $6.0 \mathrm{~g}$ of amylase from $A$. niger $/ \mathrm{kg}$ of grain improved the in vitro DM digestion of corn grain, but only the highest level of enzyme treatment improved the digestion of sorghum. Ruminal in situ DM digestion of corn and sorghum grain was increased with amylase from $B$. licheniformis and glucoamylase from $A$. niger (Gutiérrez et al., 2005).

The high activity of $7 \mathrm{~B}$ at $\mathrm{pH}$ values similar to that found in the rumen, its high stability in ruminal fluid, and its ability to improve in vitro ruminal VFA production from some types of corn grain suggested that this enzyme additive was a good candidate for use in diets of lactating cows. Treatment of the concentrate with the high dose of 7B resulted in a $7.4 \%$ increase in DMI compared with cows fed diets without enzymes. However, this stimulation in intake was not accompanied 
Table 5. Least squares means of production measurements in the lactation trial

\begin{tabular}{|c|c|c|c|c|c|}
\hline \multirow[b]{2}{*}{ Item } & \multicolumn{4}{|c|}{ Treatment $^{1}$} & \multirow[b]{2}{*}{ SEM } \\
\hline & $\mathrm{CON}$ & $7 \mathrm{BL}$ & $7 \mathrm{BH}$ & AMA & \\
\hline DMI, $\mathrm{kg} / \mathrm{d}$ & $27.0^{\mathrm{b}}$ & $28.1^{\mathrm{ab}}$ & $29.0^{\mathrm{a}}$ & $28.5^{\mathrm{a}}$ & 0.5 \\
\hline Milk, kg/d & $43.2^{\mathrm{b}}$ & $47.1^{\mathrm{a}}$ & $44.2^{\mathrm{b}}$ & $45.2^{\mathrm{ab}}$ & 0.7 \\
\hline \multicolumn{6}{|l|}{ Milk fat } \\
\hline$\%$ & 2.98 & 2.99 & 3.09 & 3.08 & 0.07 \\
\hline $\mathrm{kg} / \mathrm{d}$ & $1.28^{\mathrm{b}}$ & $1.39^{\mathrm{a}}$ & $1.35^{\mathrm{ab}}$ & $1.40^{\mathrm{a}}$ & 0.04 \\
\hline \multicolumn{6}{|l|}{ Milk protein } \\
\hline$\%$ & 2.88 & 2.89 & 2.88 & 2.90 & 0.02 \\
\hline $\mathrm{kg} / \mathrm{d}$ & $1.24^{\mathrm{c}}$ & $1.36^{\mathrm{a}}$ & $1.27^{\mathrm{bc}}$ & $1.30^{\mathrm{ab}}$ & 0.02 \\
\hline $3.5 \%$ FCM, $\mathrm{kg} / \mathrm{d}$ & $39.4^{\mathrm{b}}$ & $43.0^{\mathrm{a}}$ & $41.0^{\mathrm{ab}}$ & $42.3^{\mathrm{a}}$ & 0.8 \\
\hline FCM $/ \mathrm{DMI}, \mathrm{kg} / \mathrm{d}$ & $1.47^{\mathrm{ab}}$ & $1.55^{\mathrm{a}}$ & $1.43^{\mathrm{b}}$ & $1.49^{\mathrm{ab}}$ & 0.03 \\
\hline MUN, mg/dL & $14.8^{\mathrm{ab}}$ & $14.9^{\mathrm{ab}}$ & $14.5^{\mathrm{b}}$ & $15.4^{\mathrm{a}}$ & 0.3 \\
\hline Milk lactose, \% & 4.79 & 4.75 & 4.75 & 4.82 & 0.03 \\
\hline $\mathrm{BW}, \mathrm{kg}$ & 748 & 756 & 749 & 755 & 15 \\
\hline BW change, kg/d & 1.11 & 1.51 & 1.17 & 1.46 & 0.34 \\
\hline
\end{tabular}

${ }^{\mathrm{a}-\mathrm{c}}$ Means in rows with unlike superscript letters differ $(P<0.05)$.

${ }^{1} \mathrm{CON}=$ untreated $($ control $) \mathrm{TMR} ; 7 \mathrm{BL}$ and $7 \mathrm{BH}=\mathrm{TMR}$ treated with a low $(0.88 \mathrm{~mL} / \mathrm{kg}$ of TMR DM) or high $(4.4 \mathrm{~mL} / \mathrm{kg}$ of TMR DM) dose of the experimental amylase enzyme, 7B (Dutch States Mines, Heerlen, the Netherlands); AMA = TMR treated with a commercially available enzyme product (Amaize, Alltech Inc.,

Nicholasville, KY) with amylase activity, applied at $0.4 \mathrm{~g} / \mathrm{kg}$ of TMR DM.

by an improvement in milk production or BW change. The lower dose of $7 \mathrm{~B}$ did not statistically improve intake but it was numerically greater than in cows fed CON. For the addition of $7 \mathrm{~B}$, only the low dose (7BL) improved milk and 3.5\% FCM production when compared with the control but the increase was substantial $(+3.9 \mathrm{~kg}$ of milk and $+3.6 \mathrm{~kg}$ of $3.5 \% \mathrm{FCM} / \mathrm{d})$. Adding AMA to the diets of lactating dairy cows also improved $3.5 \%$ FCM. Other studies have examined the effects of feeding AMA to ruminants. Tricarico et al. (2005) fed cows a diet without enzymes or diets with 3 different levels of AMA. In contrast to our studies, AMA did not affect DMI in that study but it resulted in a quadratic increase in milk production, with the lowest dosage having the greatest effect. Harrison and Tricarico (2007) reported an increase in milk production when
AMA was fed to commercial dairy herds but DeFrain et al. (2005) did not observe any effects of AMA on DMI or milk production during lactation. When AMA was fed to finishing beef cattle, quadratic responses in ADG and DMI were reported (Tricarico et al., 2007a). Overtreatment with enzymes could negate potential positive effects from enzymes and may explain the lack of effect from $7 \mathrm{BH}$ in our study, as quadratic effects of enzyme doses have been previously observed. For example, Kung et al. (2000) reported that cows fed a low level of a fibrolytic enzyme mixture sprayed on the TMR before feeding produced more milk than cows fed a diet treated with a higher level of the same enzyme mixture. Similarly, Beauchemin et al. (1995) reported that a low, but not high, application of fibrolytic enzymes to alfalfa hay increased ADG in steers. Tanaka

Table 6. Dry matter intake and apparent digestibility of the TMR from the digestion study in the lactation trial

\begin{tabular}{llllll}
\hline & \multicolumn{5}{c}{ Treatment $^{1}$} \\
\cline { 2 - 4 } Item & CON & $7 \mathrm{BL}$ & $7 \mathrm{BH}$ & AMA & SEM \\
\hline DMI, kg/d & 29.6 & 26.2 & 28.3 & 27.1 & 1.3 \\
DM, \% & & & & & 1.4 \\
OM, \% & $63.0^{\mathrm{bc}}$ & $68.6^{\mathrm{a}}$ & $60.5^{\mathrm{c}}$ & $65.7^{\mathrm{ab}}$ & 1.5 \\
CP, \% & $65.3^{\mathrm{bc}}$ & $69.9^{\mathrm{a}}$ & $61.7^{\mathrm{c}}$ & $67.4^{\mathrm{ab}}$ & 1.8 \\
ADF, \% & $66.2^{\mathrm{ab}}$ & $70.0^{\mathrm{a}}$ & $61.8^{\mathrm{b}}$ & $667^{\mathrm{ab}}$ & 3.0 \\
NDF, \% & 27.1 & 32.9 & 27.3 & $39.2^{\mathrm{ab}}$ & 3.8 \\
Starch, \% & $30.0^{\mathrm{bc}}$ & $40.8^{\mathrm{a}}$ & $25.9^{\mathrm{c}}$ & $94.1^{\mathrm{ab}}$ & 0.8 \\
\hline
\end{tabular}

${ }^{\mathrm{a}-\mathrm{c}}$ Means in rows with unlike superscript letters differ $(P<0.05)$.

${ }^{1} \mathrm{CON}=$ untreated $($ control $) \mathrm{TMR} ; 7 \mathrm{BL}$ and $7 \mathrm{BH}=\mathrm{TMR}$ treated with a low $(0.88 \mathrm{~mL} / \mathrm{kg}$ of TMR DM) or high $(4.4 \mathrm{~mL} / \mathrm{kg}$ of TMR DM) dose of the experimental amylase enzyme, 7B (Dutch States Mines, Heerlen, the Netherlands); AMA = TMR treated with a commercially available enzyme product (Amaize, Alltech Inc., Nicholasville, KY) with amylase activity, applied at $0.4 \mathrm{~g} / \mathrm{kg}$ of TMR DM. 
et al. (1988) hypothesized the negative effects of high cellulase levels might be due to low-molecular-weight cellulases moving into small pores on the surface of fiber that are inaccessible to larger enzyme molecules with the result of reduced synergistic effects of the enzymes from the cellulase complex. In addition, Treacher and Hunt (1996) hypothesized that overtreatment with enzymes might hamper attachment of rumen bacteria to feeds and thus might decrease rumen digestibility. Similar processes may be occurring with high levels of amylase enzymes.

The level of AMA used in our study was based on the findings of Tricarico et al. (2005) and theoretically supplied 240 dextrinizing units per $\mathrm{kg}$ of TMR fed (DM basis). When the $\alpha$-amylase activity of $7 \mathrm{~B}$ and AMA at a $\mathrm{pH}$ of 6.0 (similar to the $\mathrm{pH}$ of the rumen of a cow fed a diet high in concentrate) were converted to doses used in the lactation trial, 7BL was applied at 5,635 $\mathrm{CU} / \mathrm{kg}$ of TMR DM, 7BH at $28,176 \mathrm{CU} / \mathrm{kg}$ of TMR DM, and AMA was applied at $94 \mathrm{CU} / \mathrm{kg}$ of TMR DM. The large differences in added amylase activity between AMA and 7B but similar response in 3.5\% FCM in our lactation trial is difficult to explain. However, others have shown positive effects of feeding amylase enzymes to ruminants. Tricarico et al. (2007b) proposed a hypothetical mode of action for amylase that suggests the production of oligosaccharides from amylose and amylopectin from low (but not high) levels of amylase stimulates the cross-feeding mechanisms of some rumen bacteria. For example, their studies have shown that Selenomonas ruminantium, Megasphaera elsdenii, and Butyrivibrio fibrisolvens grew poorly on starch but grew rapidly when an amylase was added to the starchcontaining medium. The release of maltodextrins (a breakdown product of native starch) by the enzyme was used for growth. In contrast, high enzyme doses would extensively digest starch to di- and monosaccharides not participating in the similar cross-feeding mechanisms. Another important aspect of the AMA treatment is that the product also contained $S$. cerevisiae fermentation solubles, which may have contributed to a positive ruminal response.

Cows fed 7BL had better digestion of DM and OM relative to cows fed CON. These findings may partially explain the improvement in milk production found for that treatment, but intakes during the digestion phase of the study were numerically lower for cows fed $7 \mathrm{BL}$ and AMA compared with CON, which could have been partly responsible for the improvement in digestibility. The greater digestibility of NDF in 7BL compared with CON initially appears to be substantial. However, it should be noted that the coefficient of variation was very large for this variable (and $\mathrm{ADF}$ ). In fact, the digestibility of NDF in the TMR fed to cows receiving
7BL and AMA were similar to that reported by Harvatine and Allen (2006) but were much lower for cows fed $\mathrm{CON}$ and $7 \mathrm{BH}$. This suggests that NDF digestibility may have actually been lower than normal for CON and $7 \mathrm{BH}$, and we do not have an explanation for this finding at this time. However, Chen et al. (1995) added a fungal-derived enzyme complex with amylolytic and proteolytic activities to steam-flaked and dry-rolled sorghum grain fed to lactating cows. In that study $\mathrm{DM}, \mathrm{OM}, \mathrm{CP}$, and NDF digestibility were enhanced by those enzymes although treatment did not affect milk production or DMI. In contrast, amylase enzymes did not affect the digestibility of nutrients in the total tract in the studies of Tricarico et al. (2005) and Hristov et al. (2008); in those 2 studies amylase activity was also from AMA.

\section{CONCLUSIONS}

Experimental and commercial enzyme formulations had substantial activities of $\alpha$-amylase in a $\mathrm{pH}$ range of 5.1 to 6.3 , which can be found in the rumens of high-producing dairy cows. However, the experimental formulation contained much higher amylase activity than the commercial formulation. Both formulations were stable in in vitro ruminal fermentations. A low dose, but not a high dose, of the experimental enzyme mixture 7B increased milk and FCM production and had no effect on DMI. Dry matter intake and FCM production was improved by feeding the commercial enzyme formulation AMA. Exogenous amylase enzymes have the potential to increase intake and improve milk production but the exact mechanism of how this occurs is unknown at this time.

\section{ACKNOWLEDGMENTS}

The authors gratefully acknowledge partial funding for this project from Dutch States Mines (Heerlen, the Netherlands). The authors thank Renato Schmidt, Maggie Morris, Caroline Golt, and the farm crew at the University of Delaware farm for their assistance throughout these studies. We are especially indebted to Richard Morris, herdsman of the University of Delaware Dairy, for his exceptional support with the animal studies.

\section{REFERENCES}

Anonymous. 1989. Handbook for Agricultural Animal Care and Use in Research and Teaching. Agricultural Animal Care and Use Committee, Univ. Delaware, Coll. Agric. Natural Res., Newark.

AOAC. 2000. Ash of animal feed; method 942.05. Official Methods of Analysis. 17th ed. AOAC, Gaithersburg, MD.

Bach, A., C. Iglesias, and M. Devant. 2007. Daily rumen $\mathrm{pH}$ pattern of loose-housed dairy cattle as affected by feeding pattern and live yeast supplementation. Anim. Feed Sci. Technol. 136:146-153. 
Baks, T., A. Janssen, and R. M. Boom. 2006. The effect of carbohydrates on $\alpha$-amylase activity measurements. Enzyme Microb. Technol. 39:114-119.

Beauchemin, K. A., D. Colombatto, D. P. Morgavi, and W. Z Yang. 2003. Use of exogenous fibrolytic enzymes to improve feed utilization by ruminants. J. Anim. Sci. 81(E Suppl. 2):E37-E47.

Beauchemin, K. A., L. M. Rode, and V. J. H. Sewalt. 1995. Fibrolytic enzymes increase fiber digestibility and growth rate of steers fed dry forages. Can. J. Anim. Sci. 75:641-644.

Blasel, H. M., P. C. Hoffman, and R. D. Shaver. 2006. Degree of starch access: An enzymatic method to determine starch degradation potential of corn grain and corn silage. Anim. Feed Sci. Technol. 128:96-107.

Bowman, G. R., K. A. Beauchemin, and J. A. Shelford. 2002. The proportion of the diet to which fibrolytic enzymes are added affects nutrient digestion by lactating dairy cows. J. Dairy Sci. $85: 3420-3429$

Chen, K. H., J. T. Huber, J. Simas, C. B. Theurer, P. Yu, S. C. Chan, F. Santos, Z. Wu, and R. S. Swingle. 1995. Effect of enzyme treatment or steam-flaking of sorghum grain on lactation and digestion in dairy cows. J. Dairy Sci. 78:1721-1727.

DeFrain, J. M.. A. R. Hippen, K. F. Kalscheur, and J. M. Tricarico. 2005. Effects of dietary $\alpha$-amylase on metabolism and performance on transition cows. J. Dairy Sci. 88:4405-4413.

FASS. 1999. Guide for the Care and Use of Agricultural Animals in Agricultural Research and Teaching. 1st rev. ed. Fed. Anim. Sci. Soc., Savoy, IL.

Food Chemicals Codex. 1996. 4th ed. Natl. Acad. Press, Washington, $\mathrm{DC}$

Freer, S. N. 1993. Purification and characterization of the extracellular alpha-amylase from Streptococcus bovis JB1. Appl. Environ. Microbiol. 59:1398-1402.

Goering, H. K., and P. J. Van Soest. 1970. Forage Fiber Analyses (Apparatus, Reagents, Procedures, and Some Applications). Agric. Handbook. No 379. ARS-USDA, Washington, DC.

Gutiérrez, C., G. D. Mendoza, R. Ricalde, L. M. Melgoza, and F. Plata. 2005. Effect of exogenous amylase or glucoamylase dose on in situ ruminal digestion of corn and sorghum. J. Appl. Anim. Res. 27:7-10.

Harrison, G. A., and J. M. Tricarico. 2007. Effects of an Aspergillus oryzae extract containing $\alpha$-amylase activity on lactational performance in commercial dairy herds. Prof. Anim. Sci. 23:291294

Harvatine, K. J., and M. S. Allen. 2006. Effects of fatty acid supplements on ruminal and total tract nutrient digestion in lactating dairy cows. J. Dairy Sci. 89:1092-1103.

Holm, J., I. Bjorck, A. Drews, and N. G. Asp. 1986. A rapid method for the analysis of starch. Starch/Starke 7:224-226.

Hristov, A. N., C. E. Basel, A. Melgar, A. E. Foley, J. K. Ropp, C. W. Hunt, and J. M. Tricarico. 2008. Effect of exogenous polysaccharide degrading enzyme preparations on ruminal fermentation and digestibility of nutrients in dairy cows. Anim. Feed Sci. Technol. 145:182-193

Hristov, A. N., T. A. McAllister, and K. J. Cheng. 1998. Stability of exogenous polysaccharide-degrading enzymes in the rumen. Anim. Feed Sci. Technol. 76:161-168.

International Association for Cereal Science and Technology. 1998. Simple and specific assay for alpha-amylase. ICC rapid method no. 303. http://www.icc.or.at/methods3.php\#ICC303. Accessed Sept. 15, 2007

Krishnamoorthy, U., T. V. Muscato, C. J. Sniffen, and P. J. Van Soest. 1982. Borate-phosphate procedure as detailed in nitrogen fractions in selected feedstuffs. J. Dairy Sci. 65:217-225.

Kung, L. Jr., R. J. Treacher, G. A. Nauman, A. M. Smalgala, K. M. Endres, and M. A. Cohen. 2000. The effect of treating forages with fibrolytic enzymes on its nutritive value and lactation performance of dairy cows. J. Dairy Sci. 83:115-122.

McCleary, B. V., M. McNally, D. Monaghan, and D. C. Mugford. 2002. Measurement of alpha-amylase activity in white wheat flour, milled malt, and microbial enzyme preparations, using the Ceralpha assay: collaborative study. J. AOAC Int. 85:1096-1102.

Mora-Jaimes, G., R. Barcena-Gama, G. Mendoza-Martinez, S. Gonzalez-Munoz, and J. Herrera-Haro. 2002. Performance and ruminal fermentation in lambs fed sorghum grain treated with amylases. Agrociencia 36:31-39

Najafi, M. F., D. Deobagkar, and D. Deobagkar. 2005. Purification and characterization of an extracellular $\alpha$-amylase from Bacillus subtilis AX20. Protein Expr. Purif. 41:349-354.

Oba, M., and M. S. Allen. 1999. Effects of brown midrib 3 mutation in corn silage on dry matter intake and productivity of high yielding dairy cows. J. Dairy Sci. 82:135-142.

Planchot, V., and P. Colonna. 1995. Purification and characterization of extracellular alpha-amylase from Aspergillus fumigatus. Carbohydr. Res. 272:97-109.

Rojo-Rubio, R., G. D. Mendoza-Martinez, and M. M. Crosby-Galvan. 2001. Use of thermostable amylase from Bacillus licheniformis on in vitro starch digestion of sorghum and corn. Agrociencia $35: 423-427$.

SAS Institute. 2004. SAS User's Guide. SAS Institute Inc., Cary, NC.

Singh, H., and S. K. Soni. 2001. Production of starch-gel digesting amyloglucosidase by Aspergillus oryzae HS-3 in solid state fermentation. Process Biochem. 37:453-459.

Snedecor, G. W., and W. G. Cochran. 1980. Statistical Methods. 6th ed. Iowa State Univ. Press, Ames.

Tanaka, M., M. Ikesaka, R. Matsuno, and A. O. Converse. 1988. Effect of pore size in substrate and diffusion of enzymes on hydrolysis of cellulose material with cellulase. Biotechnol. Bioeng. 32:698706

Treacher, R. J., and C. W. Hunt. 1996. Recent developments in feed enzymes for ruminants. Pages $37-54$ in Proc. Pac. NW Anim. Nutri. Conf., Seattle, WA. Pac. NW Nutr. Conf., Portland, OR.

Tricarico, J. M., M. D. Abney, M. L. Galyean, J. D. Rivera, K. C Hanson, K. R. McLeod, and D. L. Harmon. 2007a. Effects of a dietary Aspergillus oryzae extract containing $\alpha$-amylase activity on performance and carcass characteristics of finishing beef cattle. J. Anim. Sci. 85:802-811.

Tricarico, J. M., J. D. Johnston, and K. A. Dawson. 2007b. Dietary supplementation of ruminant diets with an Aspergillus oryzae

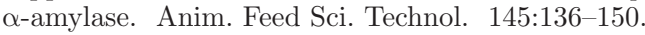

Tricarico, J. M., J. D. Johnston, K. A. Dawson, K. C. Hanson, K. R. McLeod, and D. L. Harmon. 2005. The effects of an Aspergillus oryzae extract containing alpha-amylase activity on ruminal fermentation and milk production in lactating Holstein cows. Anim. Sci. 81:365-374.

Uguru, G. C., D. A. Robb, J. A. Akinyanju, and A. Sani. 1997. Purification, characterization and mutagenic enhancement of a thermoactive alpha-amylase from Bacillus subtilis. J. Ind. Microbiol. Biotechnol. 19:273-279.

Velasco, R. R. 2004. Effect of $\alpha$-amylase (Bacillus licheniformis) dose, solution, temperature, and ground Sorghum grain on starch agglutination and ruminal digestibility in vitro. Interciencia 29:686-691.

Walsh, G., R. A. Murphy, G. F. Killeen, and R. F. Power. 2005. Quantification of supplemental enzymes in animal feedstuffs by radial enzyme diffusion. Appl. Microbiol. Biotechnol. 67:70-74.

Yang, W. Z., K. A. Beauchemin, and L. M. Rode. 2000. A comparison of methods of adding fibrolytic enzymes to lactating cow diets. J. Dairy Sci. 83:2512-2520. 